2 Citation: Chang, C.Y., W.J. Pan and R. Howard (2017) Impact of Building Information

3 Modelling Implementation on the Acceptance of Integrated Delivery Systems: Structural

4 Equation Modelling Analysis, Journal of Construction Engineering and Management.

\title{
Impact of Building Information Modelling Implementation on the Acceptance of Integrated Delivery Systems: Structural Equation Modelling Analysis
}

\author{
Chen-Yu Chang ${ }^{1}$ \\ Weijia Pan $^{2}$ \\ Robert Howard ${ }^{3}$
}

\begin{abstract}
In recent years, Building Information Modelling (BIM) has been increasingly employed by the Architecture, Engineering and Construction industry worldwide as a result of digital government initiatives. In spite of some promising early evidence on the benefits of BIM, the momentum of this "top-down" drive should build upon after-implementation empirical evidence. Through the structural equation modeling analysis of survey returns from 145 Chinese BIM-enabled projects, this research demonstrates that BIM's degree of implementation can positively affect the acceptability of Integrated Project Delivery (IPD) in the future via increased perception of the need for supply chain incentivization and improved communication quality enabled by BIM. Rolling out BIM on a wider scale may yield an additional benefit in lowering the barrier to the implementation of IPD systems. This finding can serve as evidential support for government mandates that requires the compulsory adoption of BIM in public projects.
\end{abstract}

Keywords: integrated project delivery, building information modeling, structural equation modeling, collaboration, incentivization

\footnotetext{
${ }^{1}$ Director, Bartlett Infrastructure Center, University College London, 1-19 Torrington Place, London WC1E 7HB. Email: chen-yu.chang@ucl.ac.uk

${ }^{2}$ Master student, Bartlett School of Construction and Project Management, University College London, 1-19 Torrington Place, London WC1E 7HB. Email: weijia.pan.14@ucl.ac.uk

$3 \mathrm{PhD}$ candidate, Bartlett School of Construction and Project Management, University College London, 1-19

Torrington Place, London WC1E 7HB. Email: robert.howard.09@ucl.ac.uk
} 


\section{Introduction}

In recent years, Building Information Modelling (BIM) has been enthusiastically promoted by governments worldwide with the diffusion of BIM in fact driven primarily by means of government mandates. For instance, the recent outgrowth of BIM in the United Kingdom can be largely attributed to the government's target of having Level-2 BIM adopted in all central government sponsored projects by 2016. Initially, this "top-down" drive for BIM implementation was built upon the early evidence on BIM benefits including miscellaneous cost savings (e.g., collision detection) or direct return on investment. However, such a drive could lose momentum after a large-scale implementation without further evidential support. In the initial stage, the high setup cost of BIM (hardware and software costs as well as training costs) could not be justified by the benefits resulting from its deployment. Lack of a selfsustaining economic case for individual users may result in resistance to increase the adoption of BIM, which in turn will undermine the rationale of BIM mandates. In the policy cycle, evaluation and feedback are the essential elements (HM Treasury, 2015). For a technology as transformative as BIM, it is imperative to evaluate its benefit from the perspective of the industry's long-term development. This research brings to light a hitherto unexplored benefit from the widespread application of BIM as a result of government mandate: its ability to increase BIM users' awareness of the significance of integrated delivery models which can, in turn, precipitate the acceptance of these models moving forward. This cause-effect relation evinces that the enabling function of BIM does not only result in quantitative changes (e.g., steady improvements in cost) to projects but also qualitative changes (e.g., greater employment of integrated delivery systems) to the industry at large.

Integrated Project Delivery (IPD) aims to improve project outcomes through a collaborative approach of aligning the incentives and goals of the project team via shared risk and reward, contractor early involvement, and a multiparty agreement. Since both BIM and IPD compel a dramatic increase in information sharing, these concepts have become intertwined (Eastman, et al, 2011), with many going so far as to claim that IPD is pivotal to BIM implementation (Sebastian, Haak \& Vos, 2009). This provides a central piece of evidence to understand the reinforcement effect of BIM on the evolution of integrated delivery environments. Similar to the S-curve trajectory in the development of other technologies, the diffusion of BIM has an uphill climb during the early stages (see the discussion section for detail). Without strong driving forces, this "gravity" cannot be easily surmounted leading to the slow diffusion of BIM. As well known in physics, the force required to move a still object (i.e., static friction) is much higher than that necessary to maintain the speed of a moving object (i.e., kinetic friction). This illustrates why a growing number of governments opted for a powerful tool such as a policy mandate to set in motion large-scale BIM implementation in hopes that its diffusion would be self-sustaining thereafter. Following such a mandated implementation, resistance could primarily stem from BIM participants in circumstances where their interests are not aligned and thus the application of incentivization measures could help propel BIM participation. However, these measures could reach limitation if not embedded in an integrated delivery system. As the implementation of incentivisation systems and delivery systems involve a steep learning curve for all parties involved, according to the Technology Acceptance Model user resistance could become a major hindrance to the realization of BIM's full potential. The main intellectual contribution of this research lies in the discovery of a set of statistically robust results to demonstrate that the compulsory adoption of BIM could lead to a cycle in which the experience of using BIM translates into the momentum for ushering in a desirable BIM delivery environment (i.e., IPD).

From May 2015, the Chinese government published a series of national standards for utilizing BIM and regulations related to BIM implementation. In July 
2014, the Department of Housing Construction issued the Suggestion for Advancing Construction Reform and Development (as cited in Ni \& Wang, 2015) which requires promoting the use of information technology in the whole project life-cycle. This document document also indicated that by the end of 2020, the ratio of projects using BIM in medium and large public building projects, public green building projects and green demonstration housing projects must achieve $90 \%$. The overall adoption rate of BIM in China remains considerably lower than that of developed countries (as cited in Cao et al., 2015). The use of BIM in China to date is still limited principally to visualization. With the strong drive from the Chinese central government, it can be expected that BIM will proliferate fast in the Chinese Architecture/Engineering/ Construction (AEC) industry. Given the predominance of the traditional design-bid-build delivery system in China, Chinese BIM users will come to realize that BIM cannot reach its full benefit in improving project coordination without introducing collaborative delivery systems. In this research, Integrated Project Delivery (IPD) is chosen as the exemplar collaborative project governance owing to its strong influence in the US construction industry. With survey returns from 145 Chinese BIM-enabled projects, this research demonstrates statistically that the acceptance of IPD features increases with the use of BIM applications through two channels: one via the improved awareness of incentivization being a crucial element in governing BIM-enabled projects; the other by improved communication quality affected by BIM. The value of this research can be seen in two aspects: First, it has become an official practice that regulatory measures should be subject to a riskbased assessment (Löfstedt, 2004; Organisation For Economic Cooperation and Development, 1997) by weighing up regulatory risks against the attendant benefits. This finding can be drawn upon as an additional benefit by any government to justify the implementation of a new BIM mandate or the broadening/deepening of an existing mandate. Second, this finding opens a new frontier for BIM research as BIM's spill-over effect on IPD acceptance could ultimately be as significant as the BIM benefits already reported within literature. Addressing this fact is a first step to developing a life-cycle theory of BIM diffusion.

\section{Literature review}

BIM has the potential to be a game-changing factor in the industry for three reasons (Eastman et al., 2011): First, it is a unique way of integrating information into design schematics. Second, BIM can be easily standardized. Third, by accommodating all information into virtual models, BIM provides an opportunity to improve quality assurance through the formalization of model specifications. As a result, BIM can be perceived both as a "technology" and a "process" (Tahrani et al., 2015). In pursuit of these benefits, several countries (e.g., Singapore, South Korea, the United Kingdom, and the United States) have mandated the compulsory use of BIM in public projects (Cao et al., 2015). However, BIM is just beginning to register significant awareness and adoption within the industry at large. Eadie et al.'s (2012) recent investigation show that contractors are less involved in BIM use than designers and many BIM practices are limited to the design stage. While one can derive benefits from BIM in separate applications, only when BIM is embedded in the process to generate the interoperable and interactive workflow around it can the full potential of BIM be unlocked (Monteiro, Meda and Martins, 2014). This requires a new form of delivery system that supports collaborative procurement processes (Australasia, 2012). It is widely recognized that IPD could be an organizational solution (Australasia, 2012; McGraw Hill Construction, 2014). As argued by Succar (2009), BIM development may go through three stages (object-based modeling, model-based collaboration and network-based integration) before it reached the long-term goal of embedding BIM in an IPD environment. Behind this evolution, there are three interlocking driving forces at work, which are associated with policy, technology and process. Along the similar line, Succar and Kassem (2015) develop five models for the assessment and 
management of BIM diffusion (diffusion areas model, macro maturity components model, macro diffusion dynamics model, policy actions model, and macro diffusion responsibilities model). There is ample evidence from the US, UK, and China that project delivery systems with a higher level of integration could lead to better project outcomes (Chen \& Jiao, 2011; Korkmaz et al., 2010; AIA, 2007). There is also a view that a BIM-enabled collaborative environment could facilitate the implementation of IPD (Cohen, 2010). While IPD principles have been promoted for over a decade, IPD projects remain uncommon (Kent et, al., 2010). Illdevised legal frameworks, inadequate competencies, and lack of experience have all impeded the adoption of IPD (Autodesk White Paper, 2008). Most existing IPD contracts include elements that are designed to encourage teamwork for the success of the entire project rather than any particular team member. Unlike traditional projects where all parties pursue own risk minimisation, IPD combines the risks and rewards of all team members and correlates them with common project goals (Kent et al., 2010). Generally, interest alignment holds the key to the success of integration. As defined in Baddeley \& Chang (2015), 'incentivization' refers to the act of employing measures that help align the divergent interests of BIM participants. Chang (2014) and Chang \& Howard (2016) identified seven fundamental questions involved in the design of a BIM incentivisation system and their theoretical foundations:

1) How to manage the coevolution of design and target cost?

2) How to fund the incentive pool?

3) On what basis to award compensation?

4) What weightings to assign to objective and subjective evaluation?

5) How to allocate risk through the choice of risk-sharing ratio?

6) How to choose the right compensation from between linear and non-linear plans?

7) How to set the threshold value for each incentive award band?

The current research adopts these BIM incentivization questions and previous research results as the theoretical frame of reference.

Within the project environment, BIM's greatest effects relate to communication (Mourshed, 2006). Trust and communication are critical to effective supply chain relationships (Baddeley $\&$ Chang, 2015). The processes for the extraction, interpretation and communication of design information from drawings and documents are frequently time-consuming and arduous (Sebastian, 2010). However, BIM protocols can help facilitate this process. For example, during the construction process, BIM can support communication among parties and locations (e.g., the building site, the factory and the design office), which is crucial for efficient prefabrication and assembly, as well as prevention of unexpected errors.

As maintained by Brennan (2011), effective communication, trust, and respect are among the most important critical success factors (CSF) for team collaboration under an IPD approach. Adding communication into the IPD acceptability model begs the fundamental question of how to measure the quality of communication. As cited in Mohr and Spekman (1994), communication quality is a critical aspect of information transmission, including issues such as the accuracy, timeliness, adequacy, and credibility of the information exchanged. In a recent study of trust in Chinese IPD teamwork, Wu (2012) identified communication as one of the major indicators of project performance and measured it using three dimensions, including communication effectiveness, accuracy and degree of involvement. By also reference to Freeman, et al. (2006) and Pocock, et al. (1996), the current research takes a broader view by defining communication quality as consisting of accuracy, timeliness, transparency, initiative and frequency.

Large construction projects mostly span several years in which the interaction between owner and contractor could be intense (Kadefors, 2003). BIM projects are aimed to enhance collaboration by improving information sharing across business 
boundaries and inter-disciplinary teams. In recent years, practitioners have become increasingly aware that efforts should be made towards removing the barriers to collaboration collaboration within the construction supply chain. Ertel, Jeff, \& Laura (2001) explored the the function of collaboration in multi-party agreements, finding that poor collaboration is the most significant factor leading to the failure of project alliances. Respondents in a recent investigation of BIM practices also observed mistrust and collaboration issues among participants in their projects (Cao et al. 2015).

IPD is an emerging delivery system in which members' success depends on collaboration and teamwork amongst main parties. Although research has demonstrated that collaboration is a critical requirement for IPD, it is not solidly grounded in empirical evidence. Only a few studies have focused on collaboration assessment and improvement. An example is Abdirad \& Pishdad-Bozorgi (2014) where the authors developed a framework of metrics for measuring collaboration within IPD, including co-location (Brewer \& Mendelson, 2003), multidisciplinary work (Brewer \& Mendelson, 2003), team productivity (Brewer \& Mendelson, 2003), cost impact of collaboration (EI Asmar, 2012), training (Thompson \& Ozbek, 2012), immediate feedback (Brewer \& Mendelson, 2003), real-time sharing of data (Moore et al., 2005), methods of communication (Thompson \& Ozbek, 2012), degree of interaction (Pocock et al., 1996), individual human aspects (i.e.turnover) and BIM technology (Cohen et al., 2010). This comprehensive list provides a sound basis for the selection of metrics used in the measurement of collaboration in the current research.

Compared to the literature, the value of the current research can be seen in three aspects: First, the focus of analysis is placed on to what extent mandated BIM implementation could change the perception of the desirability of IPD features for BIM-enabled projects. This provides a new angle for scrutinizing the benefits of BIM. The finding demonstrates that the spillover effect of using BIM, voluntarily or not, could facilitate the acceptance of IPD. The second distinguishing point lies in the empirical method used. For example, both of Succar (2009) and Succar and Kassem (2015) are prescriptive and conceptual in nature. While the framework of Succar (2009) is validated by a common qualitative approach, called "triangulation," he also calls for researchers to use different methods in testing his framework. By contrast, through the technique of Structural Equation Modelling (SEM), the current research can rigorously demonstrate that the more extensively BIM is deployed in the project, the stronger the perception of the necessity of advanced IPD features for BIM-enabled projects. This cause-effect relation suggests that BIM mandates could propel a more desirable delivery environment for high-level BIM. The model also reveals that the momentum is generated by the awareness of incentivization measures and the improvement in communication quality enabled by BIM. While the effect of BIM on the transformation of construction management work process is increasingly acknowledged (Hartmann et al., 2012; Monteiro et al., 2014), the underlying forces remain under-studied. This research furnishes timely evidence to fill this knowledge gap. Third, as elaborated in Succar and Kassem (2015), BIM diffusion could be portrayed in various ways. In the development of a parsimonious lifecycle theory of BIM diffusion, the two statistically significant constructs (incentivization and communication) found in the SEM analysis can effectively sharpen the research focus.

\section{Research Design \\ Reasons for choosing SEM}

In recent years, SEM has emerged as a mainstream analytical tool in social sciences, with the great strength of integrating confirmatory factor analysis (CFA) (Jöreskog, 1963) and path analysis (Wright, 1934), which allows a latent construct measured by multiple observed variables. Since several constructs (e.g., communication, collaboration and perceived need for 
incentivisation) considered in Figure 1 contain multi-faceted dimensions, SEM is a suitable method. The implementation of SEM below involves a two-stage procedure as suggested by Anderson and Gerbing (1988): build a measurement model first for specifying the relationships among measured variables that underlie the latent variables and then a structural model for the relationships among the latent variables.

\section{The model and hypotheses}

Based on the literature review, the core model (see Figure 1) contains five variables, of which four are latent variables (expressed by an oval), including perceived importance of BIM incentivization, communication quality, collaboration quality, and the extent of IPD acceptability. Each of these variables is comprised of several observable variables. As the scope of BIM application in a project is determined at the outset, it is treated as the independent and only exogenous variable (expressed by a rectangle). In summary, the model consists of six hypotheses:

\section{Hypothesis 1 (H1):}

The degree of BIM application can raise the perceived importance of BIM incentivization.

\section{Hypothesis 2 (H2):}

Perceived importance of BIM incentivization will have a positive effect on IPD acceptability.

\section{Hypothesis 3 (H3):}

The degree of BIM application can improve the quality of communication.

\section{Hypothesis 4 (H4):}

Better communication quality will lead to greater IPD acceptability.

\section{Hypothesis 5 (H5):}

The degree of BIM application can improve the quality of collaboration.

\section{Hypothesis 6 (H6):}

Better collaboration outcomes can increase IPD acceptability.

\section{Questionnaire Development}

This research designed a survey to elicit experts' assessment of the five constructs in Figure 1. Data was initially recorded by SPSS 19 and then entered into a structural equation model using AMOS 17. Since the quantitative approach was considered appropriate to analyze individuals' attitudes, main questions were measured on a 7-point Likert scale.

The first construct is concerned with the extent to which BIM was used in the project, which can be measured by three dimensions (see Table1): level of the BIM model (Level 0, 1, 2,3), in which project phases the model was used, and what functions BIM has assisted in serving. The four-level BIM maturity model originally developed by Bew and Richards (2008) and further enriched by the UK Government Construction Client Group (2011) has been employed in this research. This should ensure clear articulation of the standard classifications and help respondents understand the processes, tools and techniques involved in each of the BIM level defined in this model (BIS, 2011).

As the three dimensions are nesting to each other, they cannot be used as parallel constructs to form the variable. By capturing the combined effect of three dimensions reflective of the differential degree of BIM use (depth (level of BIM), breadth (number of stages applied) and scope (number of functions supported by BIM)), a multiplicative index can provide a more reliable measure than a simple additive index for the extent to which BIM has affected a project. For this reason, this construct is calculated by 
taking the multiplication of the normalized score of each dimension (see Table1 for details).

The explanatory variable in the model is to what extent the acceptance of IPD features features could change in response to the differing degree of BIM application in the project. While most of the respondents were familiar with BIM, they were less familiar with IPD and its relevant concepts. Given that there is no existing measurement of IPD acceptability, this research first identified the common features of IPD based on the literature (Cohen, 2010), and second developed the questions that can effectively elicit the respondent's view on the necessity of IPD futures for BIM-enabled projects in the future. All the features adopted were originated from IPD case studies reported in Cohen (2010). For ease of referencing, the fifteen features and their measurements are grouped into three categories: contractual, managerial and technological (see Table 2).

The second construct aims to assess the quality of collaboration. This construct is measured using several metrics discussed in the literature for measuring IPD collaboration (Brewer \& Mendelson, 2003; Abdirad \& Pishdad-Bozorgi, 2014; Moore et al., 2005; Thompson \& Ozbek, 2012; Pocock et al., 1996): aligned goals, centralized working place, multidisciplinary knowledge, and real-time information sharing.

The third construct is to evaluate the quality of communication. Aside from the traditional measures of communication quality by virtue of accuracy and timeliness (Mohr \& Spekman, 1994), three additional criteria are also included here: First, transparency reveals another aspect of communication quality as information flow within the project may be impeded by asymmetric information (Zaheer, McEvily, \& Perrone, 1998; Kadefors, 2004). Second, an initiative in participation is concerned with the degree of keenness in contributing to decisions and goal formulation within the project (Mohr \& Spekman,1994). Third, communication frequency is meant to capture how actively parties have interacted with each other in exchanging information (Mohr \& Spekman, 1994; Pocock, et. al, 1996; Freeman et al., 2006). The detail of three constructs can be found in Table3, including a brief explanation for each construct, constituent elements of each construct, their measures and notations in the model.

To fully understand the potential impact of BIM utilization on the prospect of IPD, it is essential to include all three constructs in the model. The constructs "collaboration" and "communication" both concern the actual impact of BIM on one of the 145 projects under study in these two aspects, while "incentivisation" is evaluated via the respondent's perception of the need for such an incentivisation system against his experience in a BIM-enabled project. This is because while incentivisation measures are not widely adopted in practice yet, their significance for efficiency improvement is well acknowledged in recent procurement reform (e.g. (HM Treasury, 2013)) and thus the demand for incentivisation is expected to be a crucial driver for ushering in integrated delivery systems in the future.

The data used to test the hypotheses was collected via three main methods: sending the survey link hosted on Sojump (a pay-out service similar to SurveyMonkey) direct to 170 BIM professionals (12\%); posting the online survey link on social media interest group on Sojump and Wechat (50\%); and distributing 30 questionnaires in person (28\%). In total, 163 returns were received, 145 of which were complete and can be used in the analysis. The background of the respondents spans six professions (owner, architect, engineer, general contractor, subcontractor, and consultant) which are representative of the composition of BIM participants in China (see Table 4). The majority of respondents have 6-10 years of work experience $(45.5 \%)$.

\section{Empirical Analysis}




\section{Summary statistics}

The result shows that the vast majority of projects have reached Level $1(42.8 \%)$ and $2(43.4 \%)$ with similar proportions, meaning that a managed 2D and 3D environment has been built up using BIM, but Level 3 BIM features (e.g., 4D construction sequencing, 5D (cost information) and even 6D (life-cycle information)) are not utilized yet. As revealed in Figure 2, BIM has been applied to various functions in the surveyed projects, more than $80 \%$ of which have seen BIM used to assist in design and construction.

Reliability \& Validity Test

First, the Cronbach's Alpha is used as a reliability indicator to check the internal consistency of three constructs. The results show that all possess a score of over 0.8 (BIM Incentivization Perception: 0.80; Communication Quality: 0.83; Collaboration Quality: 0.82), indicating good reliability. The next step is to examine the validity of these constructs. In statistics, the use of observed variables is based on the assumption that all these variable are valid and reliable. Through the CFA, one can determine which set of observed variables share common variancecovariance characteristics that define latent variables. The key test is to check if the sample variance-covariance data can be fit well to the specified model. As each fit index only reveals part of the model fit, it is useful to report a profile of complementary indices that cover three model fit categories: absolute fit, incremental fit and parsimonious fit.

Absolute fit indices help examine how well the theoretical model can fit the data in comparison to no model at all. The most fundamental index is the $\chi^{2}$ and its $p$-value, which is used to check whether the null hypothesis can be accepted that the sample covariance matrix is equal to the fitted one. A good fit model must lead to accepting the null hypothesis (i.e., pvalue $>0.05$ ), so $\chi^{2}$ statistic serves as a "badness of it" measure (Kline, 2016). The magnitude of $\chi^{2}$ increases with the sample size, so $\chi^{2}$ is normally reported as a ratio to the degree of freedom $(d f)$. There is a consensus that $\chi^{2} / d f$ should not exceed 3 (Kline, 2016). Apart from the sensitivity of $\chi^{2}$ to the sample size, the assumption of multivariate normality of this index could result in the rejection of a well-specified model (McIntosh, 2007). Two complimentary indices are also reported. RMSEA (Root Mean Square Error of Approximation) is an index sensitive to the number of parameters estimated in the model, so it can help choose a parsimonious model. An RMSEA below 0.08 shows a good fit (MacCallum et al., 1996). Another index is GFI (goodness of fit index), which measures the proportion of variance that can be accounted for by the model. A cut-off value of 0.9 is normally recommended (Shevlin and Miles, 1998).

Incremental fit indices allow researchers to compare a model's fit against a baseline model that assumes that all variables are uncorrelated. Comparative fit index (CFI) is a common choice. This index is in the range of 0 to 1 . A value of greater than 0.9 can ensure a poorly specified model is detected (Hu and Bentler, 1999).

Finally, it is useful to examine whether a model is accepted as a result of including unnecessary variables. The Parsimony Goodness-of-Fit Index (PGFI) developed by Mulaik et al. (1989) is calculated based on the GFI by adjusting for the loss of degrees of freedom, so it penalizes model complexity. As there is no consensus threshold level for this statistic, it should be interpreted in conjunction with other indices.

Figure 3a-c reports the result of validity test for the model. First, the loadings (standard coefficient) of the observable items on the latent variable are all above the acceptable value of 0.5. Second, the model fit is achieved compared to the threshold value of each indicator suggested in the literature. The corroboration of the validity of three constructs lays a solid foundation for the credibility of the statistical analysis

Last, the explained variable IPD Acceptability passes all the tests excepting the loading of VA5 (open-book accounting) on the sub-dimension Contractual (Figure 3d). 
Given its importance in the IPD model, VA5 is still kept in the analysis. As for reliability, the Alpha scores of three sub-dimensions are all close to the acceptable level $(0.79,0.80$ and 0.80 , respectively), so no further action was taken.

\section{Path Analysis}

The purpose of path analysis in SEM models is to test the statistical significance of the effect of explanatory variables (BIM degree, Incentivization, Communication, Collaboration) on the independent variable (IPD acceptability). The first step is to ensure that the Chi-square result is not significant through some modifications, including building correlations between the errors of VL1 \& IPD management, VL2 \& IPD acceptability, VM5 \& Collaboration, VM1 \& VM2 as well as VM3 \& IPD management. By way of this process, chi-square to the degree of freedom ratio is improved, indicating that the conceptual model is a good fit to the real data. This is also confirmed in other indicators of the model fit (see Table 4).

After estimation, it was found that the coefficient on each path, except for the one between collaboration and IPD acceptability, is significant as hypothesized (see Table 5). Specifically, a greater extent of BIM application in the project can lead to a stronger appreciation for the significance of incentivization in strengthening BIM participation (H1) and that will eventually translate into support for IPD $(\mathrm{H} 2)$. If construction professionals recognize the importance of having well-functioning incentive mechanisms in place, it will be more likely for them to accept IPD contracts and their pain/gain sharing arrangements in the future.

Also, the greater use of BIM in a project can lead to improvements in the quality of both collaboration (H3) and communication (H5). The effect of BIM degree on communication can work its way to increase IPD acceptability (H4), while this is not the case for the impact of BIM on collaboration (H6). The reason can be investigated through a mediation model (Figure 4). When modeled without including communication, collaboration has a statistically positive effect on IPD acceptability ( $\mathrm{Wc}=3.570, \mathrm{p}<0.001)$. A possible reason why H6 fails is that the two variables are completely mediated by communication (Baron \& Kenny, 1986). This conjecture is corroborated by the significance of the coefficient on the paths of collaboration to communication ( $\mathrm{Wa}=0.907, \mathrm{p}<0.001)$ and communication to IPD acceptability $(\mathrm{Wb}=3.193$, $\mathrm{p}<0.001)$. This result means that collaboration positively affected IPD acceptability through changing communication rather than affect it directly.

\section{Discussion}

Technically, BIM can provide a flexible modeling technique to visualize a design idea and store it digitally as parametric objects, which could then be fed into other analyses within the design (e.g., building services simulation) and facilitate collaborative working between project parties throughout the project lifecycle. Like other information technologies, BIM adoption is ultimately an investment decision so from a business perspective, the cost of BIM deployment must be justified by the benefits accrued from it. The sources of benefit discussed in the literature primarily concern the cost savings from early clash detection without paying much attention to the qualitative changes BIM could bring about to the construction industry in the long run. The current study represents the first attempt to take a forward-looking view on the long-term benefit of BIM. It is found that the increasing use of BIM can considerably raise practitioners' acceptance of the major IPD features which should then translate into support for implementing this system in the future. This finding can provide a key stepping stone for developing a lifecycle theory of BIM technology.

As an enabling tool, the realization of BIM's full potential depends on the readiness of all parties concerned. To secure BIM-readiness, the AEC industry needs to make a lump sum investment in hardware, software and training at the outset. The worthiness of this investment bears upon how frequently the acquired capability can be reused. In the early stage (Stage I in Figure 5), inhibited by lack of sufficient evidence in support of its benefit, the employment of 
BIM is limited to the small group of early adopters. In cash flow terms, the additional cost arising from BIM is high as most AEC companies have to build in-house capability from scratch, which will naturally constrain the feasible scope of BIM application in the project. In the environment of projects featured by a web of independent parties (designers, constructors and suppliers), the benefit of BIM can grow exponentially as its application grows broader (more lifecycle stages), deeper (levels of BIM) and more diverse (variety of analysis supported by BIM). As a result, fragmented application of BIM can only realize a small fraction of its potential. The gap in financial feasibility ( $\Delta$ in Figure 5 ) is a fundamental problem hindering the voluntary adoption of BIM. In economic terms, it can be regarded as a case of market failure under which coordination mediated by the price signal cannot occur spontaneously, and that gives a rationale for government intervention (Williamson, 1991). This could be the main reason why mandating BIM deployment in public projects is widely embraced as a kick-start strategy by governments. The nature of a government mandate is not much different than regulation as both serve to restrict the range of allowable actions for public interests. In recent decades, the pendulum of regulatory philosophies in Europe has swung to risk-based assessment in which the cost of regulation are explicitly evaluated against its benefit (Löfstedt, 2004; Organisation For Economic Cooperation and Development, 1997).

When applying the same philosophy to the design of BIM mandates, the benefit is significantly harder to evaluate than the cost because the latter involves a direct cash expenditure while the former a delayed receipt of benefit. During the development stages, the cost and benefit of BIM deployment will tend to converge as more companies upgrade to "BIM-ready" (see Figure 5). To the left of the point where those two trajectories intersect, the promotion of BIM is primarily driven by the "push" forces, such as BIM mandates. After the benefit can cover the cost (to the right of the intersection point), then "pull" forces will dominate. It is useful to understand this conversion from the perspective of the Nobel Prize awarded Principal-Agent theory (Holmstrom, 1982). In designing an optimal contract, the principal should first ensure compensation can more than cover the agent's opportunity cost. This so-called participatory condition can persuade the agent to take part but cannot induce him to exert the best effort. This theory suggests that efficiency can be improved by holding the agent accountable for the outcome of his action via risk-sharing arrangements. In the promotion of BIM, mandating can "push" some owners to embark on experimentation with the hope of driving industry BIM capability towards greater maturity through a "learning by doing" process. The push force could only make BIM nominally deployed as an enhanced 3D visualization tool, instead of giving participants strong incentives to explore the potential of BIM. For this reason, after BIM deployment becomes financially viable, the "pull" forces should be considered by way of various incentivisation measures (Chang and Howard, 2016).

When it comes to the development of BIM, the United States provides a unique case. It is instrumental to make a demarcation between the model of a BIM leader (i.e., USA) and that of BIM followers (e.g. UK, China) through the angle of a pair of contrasting concepts in Transaction Cost Economics (spontaneous v.s. intentional institution) (Williamson, 1996). As a leader for both BIM and IPD, the USA provides a desirable environment for both to crossfertilize each other. The early awareness of the reinforcement effect of BIM and IPD was well documented in US literature (e.g., Cohen, 2010). This driving force nurtured an environment for BIM to proliferate "spontaneously." However, for most countries, IPD is a system not even yet experimented with. Under the traditional design-bid-build system, key stages are separated out by design which forces BIM to be applied in isolation. To expedite the diffusion of BIM, an effective strategy for these governments is to impose "intentional institution" in the form of BIM mandate. For this reason, the initial push force is essential. In a BIM mandate, the government normally sets out requirements without providing much information about its 
rationale. A good example is from the UK Government Construction Strategy (Cabinet Office, 2011):

Government will require fully collaborative $3 D$ BIM (with all project and asset information, documentation and data being electronic) as a minimum by 2016. (p.14) In a follow-up report, several benefits were identified for BIM, including reduced lifecycle cost, potential for higher whole-life value, expanded services to clients to raise the quality of their outcomes, enhanced international competitiveness, increased offsite construction, and growing Information and Communication Technology services in construction (Saxon, 2013). This research demonstrates that utilizing BIM could have an additional benefit in raising practitioners' awareness of the importance of IPD features and that helps increase the likelihood of these features being accepted for the same project in the future.

\section{Conclusions}

In recent years, BIM has been feverishly promoted by governments throughout the world by issuing mandates to force the adoption of BIM. The justification for these mandates is restricted to current rather than long-term benefits. In addition to BIM, promoting IPD has also attracted considerable government effort (e.g. (Cabinet Office, 2014)). While IPD is not yet piloted in China, the awareness of its importance has emerged. For instance, more than half of the respondents in Ni \& Wang (2015) agreed that there should be a suitable delivery system to support BIM. The statistical analysis of this research shows that potential cost savings aside, BIM could also propel procurement reform in the long-run. This finding not only lends empirical support to the BIM mandate in China but also predicts that the wider application of BIM can facilitate the implementation of integrated delivery in the country. This evidence can also be drawn upon by governments when considering enacting a new BIM mandate or extending an existing one.

Using the data from 145 Chinse BIM-enabled projects, this research can further probe the channels through which BIM application could have impacted IPD acceptability: first, the first-hand experience of working in a BIM-enabled environment can make practitioners better appreciate the importance of incentivisation and that perception can drive the acceptability of IPD; second, observing the positive impact of BIM on communication quality can translate into another drive to support IPD. It is hoped that these robust statistical relationships can spark follow-on research to investigate the benefits of BIM in a wider context.

\section{Data Availability Statement}

Data analyzed in the study are available from the corresponding author by request.

\section{Acknowledgement}

The first author appreciates Project Management Institute for financial support from its 2015 Sponsored Research Program. 
1.Abdirad, H., \& Pishdad-Bozorgi, P. (2014). Developing a Framework of Metrics to Assess Collaboration in Integrated Project Delivery. In Proceedings of the 50th Annual International Conference of the Associated Schools of Construction, Virginia Polytechnic Institution and State University, VA, US.

2.AIA National \& AIA California Council (2007). Integrated Project Delivery: A Guide. Retrieved on 24 February 2015 from http://info.aia.org/siteobjects/files/ipd_guide_2007.pdf

3. Anderson, J.C., Gerbing, D.W. (1988). Structural equation modeling in practice: A review and recommended two-step approach. Psychological Bulletin, 103(3),411.

4. Australasia, B., 2012. National Building Information Modelling Initiative: Volume.1 Strategy.

5.Autodesk White Paper. (2008). Improving building industry results through integrated project delivery and building information modeling report on integrated practice. Retrieved on 24 February 2015 from http://images. autodesk.com/adsk/files/bim_and_ipd_whitepaper.pdf.

6.Baddeley, M., \& Chang, C. Y. (2015). Collaborative Building Information: Insights from Behavioral Economics and Incentive Theory, Royal Institution of Chartered Surveyors, London.

7.Baron, R. M., \& Kenny, D. A. (1986). The moderator-mediator variable distinction in social psychological research: Conceptual, strategic, and statistical considerations. Journal of personality and social psychology, 51(6), 1173.

8.Bew, M., and Richards, M. (2008). Bew-Richards BIM Maturity Model.

9.BIS (Department for Business, Innovation and Skills) (2011). A report for the Government Construction Client Group Building Information Modelling (BIM) Working Party Strategy Paper Retrieved on 22 November from: http://www.bimtaskgroup.org/wp-content/uploads/2012/03/BIS-BIM-strategyReport.pdf.

10. Brennan, M. D. (2011). Integrated project delivery: a normative model for value creation in complex military medical projects. Doctoral dissertation, University of Illinois at Urbana-Champaign.

11. Brewer, W., \& Mendelson, M. I. (2003). Methodology and Metrics for Assessing Team Effectiveness. The International Journal of Engineering Education, 19, 777787.

12. Browne, M. W., \& Cudeck, R. (1993). Alternative ways of assessing model fit. Sage Focus Editions, 154, 136-136.

13. Cabinet Office, (2011). Government Construction Strategy. HMSO London.

14. Cabinet Office, (2014). New Models of Construction Procurement. HMSO London.

15. Cao, D., Wang, G., Li, H., Skitmore, M., Huang, T., \& Zhang, W. (2015). Practices and effectiveness of building information modeling in construction projects in China. Automation in Construction, 49, 113-122.

16. Chang, C. (2014). An Economic Framework for Analyzing the Incentive Problems in Building Information Modeling Systems. Academy of Management Proceedings, 12276. Philadelphia, PA.

17. Chang, C.Y., Howard, R. (2016). How to incentivize BIM participation? Conceptual framework and empirical evidence. Working paper, Bartlett School of Construction and Project Management, University College London. 
18. Chen, Y. Q., \& Jiao, J. S. (2011). Influence of project delivery system and payment methods on project cost performance, Journal of Tongji University (Natural Science), 2011,09, c1407-1412.

19. Cohen, J. (2010). Integrated Project Delivery: Case Studies, AIA National, AIA California Council, AGC California and McGraw-Hill.

20. Construction, M. H. (2009). The business value of BIM. SmartMarket Report, September.

21. Ding J.Y., Wang Z.F., Anumba C., \&Wang D. (2014). A review of construction project delivery methods and project performance. China Civil Engineering Journal, 47(4), 131-144.

22. Eadie, R., Browne, M., Odeyinka, H., McKeown, C., \& McNiff, S. (2013). BIM implementation throughout the UK construction project lifecycle: An analysis. Automation in Construction, 36, 145-151.

23. Eastman, C., Eastman, C. M., Teicholz, P., \& Sacks, R. (2011). BIM Handbook: A guide to building information modeling for owners, managers, designers, engineers and contractors. John Wiley \& Sons.

24. El Asmar, M. (2012). Modeling and Benchmarking Performance for the Integrated Project Delivery (IPD) System. Ph.D. dissertation, University of Wisconsin-Madison, US.

25. Ertel, D., Jeff. W., \& Laura, V. (2001). Managing Strategic Alliances: A CrossIndustry Study of How to Build and Manage Successful Alliances. Brighton, MA: Vantage Partners.

26. Feil, P., K.-H. Yook, et al. (2004). Japanese target costing: a historical perspective. International Journal of Strategic Cost Management 11(Spring), 10-19.

27. Forbes, L. H., \& Ahmed, S. M. (2010). Modern construction: lean project delivery and integrated practices. CRC Press.

28. Freeman, J., Weil, S. A. \& Hess, K. P. (2006). Measuring, monitoring and managing knowledge in command and control organizations. In Virtual Media for Military Applications (pp.2-1-2-10), Neuilly-sur-Seine, France: RTO.

29. Gao, J., \& Fischer, M. (2008). Framework and case studies comparing implementations and impacts of 3D/4D modeling across projects, CIFE Technical Report \#TR172, Stanford University.

30. Gerschman, J., \& Schauder, J. (2006). Infrastructure Alliances: A two-edged sword. Retrieved on 24 February 2015 from http://www.cmalearning.com.au/images/stories/pdf/InfrastructureAlliances.pdf

31. Government Construction Strategy (2011). The integrated project insurance (IPI) model-project procurement and delivery guidance, HMSO, London.

32. Guion, R. M. (2002). Validity and reliability. Handbook of research methods in industrial and organizational psychology, 57-76.

33. Hartmann, T., Van Meerveld, H., Vossebeld, N., Adriaanse, A., 2012. Aligning building information model tools and construction management methods. Automation in Construction, 22(605-613.

34. HM Treasury, 2013. Infrastructure procurement route map: a guide to improving delivery capability. HMSO, London.

35. HM Treasury, 2015. The Green Book: Appraisal and Evaluation in Central Government. HMSO, London.

36. Holmstrom, B., 1982. Moral hazard in teams. The Bell Journal of Economics, 13(2),324-340. 
37. Hu, L.t., Bentler, P.M., 1999. Cutoff criteria for fit indexes in covariance structure analysis: Conventional criteria versus new alternatives. Structural Equation Modeling: A Multidisciplinary Journal, 6(1),1-55.

38. Jöreskog, K.G., 1963. Statistical estimation in factor analysis: A new technique and its foundation. Almqvist \& Wiksell, Stockholm.

39. Kadefors, A. (2004). Trust in project relationships_-inside the black box. International Journal of project management, 22(3), 175-182.

40. Kent, D. C., \& Becerik-Gerber, B. (2010). Understanding construction industry experience and attitudes toward integrated project delivery. Journal of construction engineering and management, 136(8),815-825.

41. Kline, R.B., 2016. Principles and practice of structural equation modeling. Guilford publications, New York.

42. Korkmaz, S., Swarup, L., Horman, M., Riley, D., Molenaar, K., Sobin, N., \& Gransberg, D. (2010). Influence of Project Delivery Methods on Achieving Sustainable High Performance Buildings Report on Case Studies. The Charles Pankow Foundation.

43. Lahdenperä, P. (2012). Making sense of the multi-party contractual arrangements of project partnering, project alliancing and integrated project delivery. Construction Management and Economics, 30(1), 57-79.

44. Löfstedt, R.E. (2004). The Swing of the Regulatory Pendulum in Europe: From Precautionary Principle to (Regulatory) Impact Analysis. Journal of risk and uncertainty, 28(3), 237-260.

45. Lu, W., Liu, A., Wang, H., Wu, Z. (2013). Procurement innovation for public construction projects: A study of agent-construction system and public-private partnership in China. Engineering, Construction and Architectural Management, 20(6),543-562.

46. MacCallum, R.C., Browne, M.W., Sugawara, H.M., 1996. Power analysis and determination of sample size for covariance structure modeling. Psychological methods, 1(2),130-149.

47. McGraw Hill Construction, 2014. The Business Value of BIM for Construction in Major Global Markets, Bedford, MA.

48. McIntosh, C.N., 2007. Rethinking fit assessment in structural equation modelling: A commentary and elaboration on Barrett (2007). Personality and Individual differences, 42(5),859-867.

49. Messick, S. (1989). Meaning and values in test validation: The science and ethics of assessment. Educational Researcher, 18(2), 5-11

50. Mohr, J., \& Spekman, R. (1994). Characteristics of partnership success: partnership attributes, communication behavior, and conflict resolution techniques. Strategic management journal, 15(2), 135-152.

51. Monteiro, A., Mêda, P., \& Martins, J. P. (2014). Framework for the coordinated application of two different integrated project delivery platforms. Automation in Construction, 38, 87-99.

52. Moore, P., Manrodt, K., Holcomb, M. (2005). Collaboration: Enabling synchronized supply chains. Atlanta: Capgemini, Georgia Southern University, University of Tennessee, and Intel Corporation.

53. Mourshed, M. (2006). Interoperability-based optimisation of architectural design. Department of Civil and Environmental Engineering. Cork, National University of Ireland. Ph.D. Thesis. 
54. Mulaik, S.A., James, L.R., Van Alstine, J., Bennett, N., Lind, S., Stilwell, C.D., 1989. Evaluation of goodness-of-fit indices for structural equation models. Psychological bulletin, 105(3),430.

55. Ni, H.B. \& Wang, Y. (2015). Information Technology in Chinese construction industry in 2015: Depth of using BIM and its development. Beijing: China City Press

56. Nofera, W., Korkmaz, S., Miller, V., \& Toole, T. M. (2011). Innovative features of integrated project delivery shaping project team communication. In The 2011 Engineering Project Organizations Conference.

57. Organisation For Economic Cooperation and Development, (1997). Regulatory Impact Analysis: Best Practices in OECD Countries, Paris.

58. Pennanen, A., Ballard, G., \& Haahtela, Y. (2011). Target costing and designing to targets in construction. Journal of Financial Management of Property and Construction, 16(1), 52-63.

59. Pocock, J. B., Hyun, C. T., Liu, L. Y., \& Kim, M. K. (1996). Relationship between project interaction and performance indicators. Journal of construction engineering and management, 122(2), 165-176.

60. Saxon, R.G. (2013). Growth through BIM. London: Construction Industry Council.

61. Sebastian, R. (2011). Changing roles of the clients, architects and contractors through BIM. Engineering, Construction and Architectural Management, 18(2), 176-187.

62. Sebastian, R., Haak W., Vos E. (2009) BIM Application for Integrated Design and Engineering in Small-Scale Housing Development: A Pilot Project in The Netherlands Accepted paper for International Symposium CIB-W096 "Future Trends in Architectural Management," Tainan (Taiwan), 2-3 November 2009

63. Shevlin, M., Miles, J.N., 1998. Effects of sample size, model specification and factor loadings on the GFI in confirmatory factor analysis. Personality and Individual differences, 25(1),85-90.

64. Sive, T. (2009). Integrated project delivery: Reality and Promise, a strategist's guide to understanding and marketing IPD. Society for Marketing Professional Services Foundation.

65. Succar, B., 2009. Building information modelling framework: A research and delivery foundation for industry stakeholders. Automation in construction, 18(3),357-375.

66. Succar, B., Kassem, M., 2015. Macro-BIM adoption: Conceptual structures. Automation in construction, 57(64-79).

67. Thompson, R. D., \& Ozbek, M. E. (2012). Utilization of a Co-location Office in conjunction with Integrated Project Delivery. Paper presented at the 48th ASC Annual International Conference

68. Thomsen, C., Darrington, J., Dunne, D., \& Lichtig, W. (2009). Managing integrated project delivery. Construction Management Association of America (CMAA), McLean, VA.

69. Wen, Z., Hau, K. T., \& Chang, L. (2005). A Comparison of Moderator and Mediator and Their Applications (Article written in Chinese). Acta Psychologica Sinica, 37(2), 268-274.

70. Williamson, O.E. (1991). Economic institutions: Spontaneous and intentional governance. Journal of Law, Economics, \& Organization, 7(159-187.

71. Williamson, O.E. (1996). The mechanisms of governance. Oxford University Press, New York.

72. Wright, S. (1934). The method of path coefficients. The Annals of Mathematical Statistics, 5(3),161-215. 
73. Wu, M. L., (2009). Structural Equation Model-operation and application of AMOS. Chongqing, Chongqing University Press.

74. Wu, Q (2012). A research on the influencing path of trust on management performance of Integrated Project Delivery team. Unpublished master's thesis, Tianjin University, Tianjin, China.

75. Zaheer, A., McEvily, B., \& Perrone, V. (1998). Does trust matter? Exploring the effects of interorganizational and interpersonal trust on performance. Organization Science, 9(2), 141-159.

76. Zimina, D., Ballard, G., \& Pasquire, C. (2012). Target value design: using collaboration and a lean approach to reduce construction cost. Construction Management and Economics, 30(5), 383-398 


\section{BIM Level}

In which Project Phases What functions has BIM was used? BIM assisted in serving?

Level 0: Unmanaged CAD, in 2D, with paper or electronic paper data exchanges.

Level 1: Managed CAD in 2D or 3D format with a collaborative tool providing a common data environment and standardized approach to data structure and format. Commercial data managed by standalone finance and cost management packages with no integration.

Level 2: A managed 3D environment held in separate discipline BIM tools with data attached. Commercial data managed by enterprise resource planning software and integrated by proprietary interfaces or bespoke middleware. This level of BIM may utilize 4D.

Level 3: Characterized by a fully integrated and collaborative process enabled by web services, and incorporating 4D construction sequencing, 5D cost information and $6 \mathrm{D}$ project lifecycle management information.

Normalized score $=$ number of level/4

\begin{tabular}{|c|c|}
\hline $\begin{array}{l}\text { Feasibility, } \\
\text { Concept Design, } \\
\text { Detailed Design }\end{array}$ & $\begin{array}{l}\text { - Visualization } \\
\text { - Collaborative design } \\
\text { - Space validation } \\
\text { - Environmental analysis }\end{array}$ \\
\hline $\begin{array}{l}\text { Implementation } \\
\text { Document Procurement }\end{array}$ & $\begin{array}{l}\text { Model-based } \\
\text { estimation }\end{array}$ \\
\hline Construction & $\begin{array}{l}\text { - Digital fabrication } \\
\text { - Clash detection } \\
\text { - Construction } \\
\text { simulation }\end{array}$ \\
\hline $\begin{array}{l}\text { Operation } \\
\text { Maintenance }\end{array}$ & $\begin{array}{l}\text { - Code checking } \\
\text { - Facility Management }\end{array}$ \\
\hline $\begin{array}{l}\text { Normalized score }= \\
\text { number of phases assisted } \\
\text { by BIM/6 }\end{array}$ & $\begin{array}{l}\text { Normalized score }= \\
\text { number of functions } \\
\text { served by BIM/10 }\end{array}$ \\
\hline
\end{tabular}




\begin{tabular}{|c|c|c|c|c|}
\hline Categories & Dimensions & $\begin{array}{l}\text { Representative } \\
\text { Case }\end{array}$ & Measurement & $\begin{array}{l}\text { Notation in } \\
\text { the model }\end{array}$ \\
\hline \multirow{5}{*}{ Contractual } & $\begin{array}{l}\text { Multi-party } \\
\text { contract }\end{array}$ & $\begin{array}{l}\text { Cathedral Hill } \\
\text { Hospital }\end{array}$ & $\begin{array}{l}\text { A new type of contract should be signed } \\
\text { between key project stakeholders to realize } \\
\text { co-management and promote multilateral } \\
\text { collaboration. }\end{array}$ & VA1 \\
\hline & $\begin{array}{l}\text { Incentive tied to } \\
\text { goals }\end{array}$ & $\begin{array}{l}\text { Edith Green } \\
\text { Wendell Wyatt } \\
\text { Federal } \\
\text { Building }\end{array}$ & $\begin{array}{l}\text { Financial incentives tied to goals (e.g. } \\
\text { setting target cost) should be specified in } \\
\text { legal forms that could incentivize } \\
\text { collaboration on the specific projects. }\end{array}$ & VA2 \\
\hline & Liability waiver & $\begin{array}{l}\text { SpawGlass } \\
\text { Austin } \\
\text { Regional Office }\end{array}$ & $\begin{array}{l}\text { Appropriate liability waivers can positively } \\
\text { affect the relationship between contracting } \\
\text { parties and help to resolve the dispute. }\end{array}$ & VA3 \\
\hline & $\begin{array}{l}\text { Integrated } \\
\text { project } \\
\text { insurance }\end{array}$ & $\begin{array}{l}\text { Cathedral Hill } \\
\text { Hospital }\end{array}$ & $\begin{array}{l}\text { Integrated project insurance specific to the } \\
\text { project should be used in the case of } \\
\text { unbearable project loss that the relevant } \\
\text { participants are not able to cover. }\end{array}$ & VA4 \\
\hline & $\begin{array}{l}\text { Financial } \\
\text { transparency }\end{array}$ & $\begin{array}{l}\text { MERCY \& } \\
\text { Schiller } \\
\text { Remodel }\end{array}$ & $\begin{array}{l}\text { Fiscal transparency (no hidden profits, } \\
\text { contingencies or allowance) can be accepted } \\
\text { and should be achieved by open book } \\
\text { documentation and reporting. }\end{array}$ & VA5 \\
\hline \multirow{5}{*}{ Managerial } & $\begin{array}{c}\text { Early } \\
\text { involvement }\end{array}$ & Autodesk Inc. & $\begin{array}{l}\text { Key project stakeholders should early } \\
\text { involve in the project even without the } \\
\text { contract in place for achieving collaborative } \\
\text { attitudes and improve the accuracy in } \\
\text { estimating. }\end{array}$ & VB1 \\
\hline & $\begin{array}{l}\text { Full-time } \\
\text { staffing }\end{array}$ & $\begin{array}{l}\text { Edith Green } \\
\text { Wendell Wyatt } \\
\text { Federal } \\
\text { Building } \\
\text { Modernization }\end{array}$ & $\begin{array}{l}\text { To increase the efficiency of problem } \\
\text { solving, investment should be made to } \\
\text { support full-time staffing. }\end{array}$ & VB2 \\
\hline & $\begin{array}{l}\text { Intensified } \\
\text { planning }\end{array}$ & $\begin{array}{l}\text { Sutter Health } \\
\text { Fairfield Office } \\
\text { Building }\end{array}$ & $\begin{array}{l}\text { The time-consuming process of intensified } \\
\text { planning and team building to reach the } \\
\text { aligned goals is worthwhile. }\end{array}$ & VB3 \\
\hline & $\begin{array}{l}\text { Integrated group } \\
\text { building }\end{array}$ & $\begin{array}{l}\text { Cardinal } \\
\text { Glennon } \\
\text { Children's } \\
\text { Hospital } \\
\text { Expansion } \\
\end{array}$ & $\begin{array}{l}\text { A layered interdisciplinary team (e.g. } \\
\text { Cluster Group) with open-minded members } \\
\text { should be created to ensure cross } \\
\text { collaboration and coordination between } \\
\text { groups. }\end{array}$ & VB4 \\
\hline & $\begin{array}{l}\text { Collaborative } \\
\text { decision-making }\end{array}$ & $\begin{array}{l}\text { Walter } \\
\text { Cronkite } \\
\text { School of } \\
\text { Journalism }\end{array}$ & $\begin{array}{l}\text { Increased number and frequency of meetings } \\
\text { are necessary to deal with problems and } \\
\text { assist collaborative decision making. }\end{array}$ & VB5 \\
\hline \multirow{3}{*}{ Technological } & $\begin{array}{l}\text { Co-location } \\
\text { working }\end{array}$ & $\begin{array}{l}\text { UCSF Mission } \\
\text { Bay Medical } \\
\text { Center } \\
\end{array}$ & $\begin{array}{l}\text { Co-location working has a positive effect on } \\
\text { the BIM-enabled project in general. }\end{array}$ & VC1 \\
\hline & $\begin{array}{l}\text { Necessity of } \\
\text { BIM }\end{array}$ & $\begin{array}{l}\text { St. Clare } \\
\text { Health Center }\end{array}$ & $\begin{array}{l}\text { BIM is a necessary tool for efficient sharing } \\
\text { of information in an integrated project team. }\end{array}$ & VC2 \\
\hline & $\begin{array}{c}\text { Lean } \\
\text { construction }\end{array}$ & $\begin{array}{l}\text { Sutter Health } \\
\text { Fairfield Office } \\
\text { Building }\end{array}$ & $\begin{array}{l}\text { More Lean Construction techniques (e.g. } \\
\text { Last Planner System and Target value } \\
\text { design) should be applied in project } \\
\text { implementation. }\end{array}$ & VC3 \\
\hline
\end{tabular}




\begin{tabular}{clll}
\hline $\begin{array}{c}\text { Standardized } \\
\text { documentation }\end{array}$ & $\begin{array}{l}\text { Cathedral Hill } \\
\text { Hospital }\end{array}$ & $\begin{array}{l}\text { Project documents should be standardized to } \\
\text { facilitate sharing/transferring between } \\
\text { project parties. }\end{array}$ & VC4 \\
\hline $\begin{array}{c}\text { Information } \\
\text { sharing platform }\end{array}$ & $\begin{array}{l}\text { UCSF Mission } \\
\text { Bay Medical } \\
\text { Center }\end{array}$ & $\begin{array}{l}\text { An IT platform (e.g. SMART board) should } \\
\text { be used to enable information/document } \\
\text { sharing in real time between project parties. }\end{array}$ & VC5 \\
\hline
\end{tabular}

\begin{tabular}{|c|c|c|c|}
\hline Key constructs & Dimensions & Measurement & $\begin{array}{l}\text { Notation in } \\
\text { the model }\end{array}$ \\
\hline \multirow{4}{*}{$\begin{array}{l}\text { Collaboration } \\
\text { Quality of } \\
\text { collaboration, in } \\
\text { terms of }\end{array}$} & Aligned goals & $\begin{array}{l}\text { Team members have reached an agreement on the } \\
\text { project goal and cooperate with each other } \\
\text { throughout the life-cycle. }\end{array}$ & VL1 \\
\hline & $\begin{array}{l}\text { Centralized } \\
\text { working place }\end{array}$ & $\begin{array}{l}\text { Each project party has worked in a relatively } \\
\text { centralized place and organizes regular meetings. }\end{array}$ & VL2 \\
\hline & $\begin{array}{l}\text { Multidisciplinary } \\
\text { knowledge }\end{array}$ & $\begin{array}{l}\text { Project members have possessed a certain degree of } \\
\text { multi-disciplinary knowledge and are ready to } \\
\text { collaborate with the professionals from different } \\
\text { parties. }\end{array}$ & VL3 \\
\hline & $\begin{array}{l}\text { Real-time } \\
\text { information sharing }\end{array}$ & $\begin{array}{l}\text { The project data was shared in real time among all } \\
\text { relevant project parties }\end{array}$ & VL4 \\
\hline \multirow{5}{*}{$\begin{array}{l}\text { Communication } \\
\text { Quality of real- } \\
\text { time information } \\
\text { sharing, in terms } \\
\text { of }\end{array}$} & Accuracy & $\begin{array}{l}\text { In the process of transferring information, there was } \\
\text { no distortion or incomplete messages that would } \\
\text { cause misunderstanding. }\end{array}$ & VM1 \\
\hline & Timeliness & $\begin{array}{l}\text { Project related information could be transmitted } \\
\text { timely through suitable communication platform. }\end{array}$ & VM2 \\
\hline & Transparency & $\begin{array}{l}\text { Team members were fully informed about issues } \\
\text { that affect their work, and information was not } \\
\text { hidden by any individual or small group of people. }\end{array}$ & VM3 \\
\hline & $\begin{array}{l}\text { Initiative in } \\
\text { participation }\end{array}$ & $\begin{array}{l}\text { Team members proactively participated in the goal } \\
\text { setting activities, and they would like to } \\
\text { provide/receive any information or suggestions that } \\
\text { might help the other party. }\end{array}$ & VM4 \\
\hline & $\begin{array}{l}\text { Frequency of } \\
\text { communication }\end{array}$ & $\begin{array}{l}\text { The frequency of communication is high enough to } \\
\text { support the daily exchange of working information. }\end{array}$ & VM5 \\
\hline \multirow{5}{*}{$\begin{array}{l}\text { Incentivization } \\
\text { Strength of } \\
\text { motivation for } \\
\text { pursuing the } \\
\text { interest of the } \\
\text { whole project }\end{array}$} & Monetary reward & $\begin{array}{l}\text { Financial rewards can improve the effectiveness of } \\
\text { BIM considerably better than non-monetary } \\
\text { rewards. }\end{array}$ & VI1 \\
\hline & $\begin{array}{l}\text { Group-based } \\
\text { reward }\end{array}$ & $\begin{array}{l}\text { Group based rewards will work considerably better } \\
\text { than personal rewards in incentivizing contractor } \\
\text { participation in BIM system. }\end{array}$ & VI2 \\
\hline & Objective metrics & $\begin{array}{l}\text { Objective metrics are considered better than } \\
\text { subjective ones as the basis for determining } \\
\text { incentive rewards for BIM participants. }\end{array}$ & VI3 \\
\hline & $\begin{array}{l}\text { Differentiated } \\
\text { weightings to } \\
\text { performance }\end{array}$ & $\begin{array}{l}\text { It is necessary to assign different weightings to } \\
\text { performance metrics in the determination of } \\
\text { incentive rewards for BIM participants. }\end{array}$ & VI4 \\
\hline & $\begin{array}{l}\text { Linear reward } \\
\text { sharing rule }\end{array}$ & $\begin{array}{l}\text { A simple linear reward sharing rule [e.g. reward } \\
\text { linked to a fixed percentage of cost savings] will } \\
\text { work considerably better than a more complicated } \\
\text { non-linear reward sharing rule in incentivizing } \\
\text { contractors to contribute to BIM. }\end{array}$ & VI5 \\
\hline
\end{tabular}


$\begin{aligned} & \text { Minimum amount } \\ & \text { of incentive }\end{aligned}$
$\begin{aligned} & \text { There is a minimum amount of incentive reward } \\ & \text { that can motivate contractors' full participation in }\end{aligned}$ BIM.

716

717

718

719

720

721

722

723

724

725

726

727

Table 4 Profile of the survey respondents

\begin{tabular}{lll}
\hline Years of work & $1-2$ & $9.0(\%)$ \\
experience & $3-5$ & $17.2(\%)$ \\
& $6-10$ & $45.5(\%)$ \\
& $11-20$ & $18.6(\%)$ \\
& $>21$ & $9.7(\%)$ \\
\hline Roles & Owner/developer & $10.3(\%)$ \\
& Designer & $32.4(\%)$ \\
& Engineer & $27.6(\%)$ \\
& General Contractor & $15.9(\%)$ \\
& Sub-Contractor & $3.4(\%)$ \\
& Consultant & $7.6(\%)$ \\
& Others & $2.7(\%)$ \\
\hline
\end{tabular}

Table 5 Model fit summary

\begin{tabular}{lllllll}
\hline & $\mathrm{X}^{2} / \mathrm{Df}$ & $\mathrm{P}$ & RMSEA & PGFI & GFI & CFI \\
\hline Default model & 1.059 & 0.299 & 0.020 & 0.671 & 0.904 & 0.993 \\
Criteria of good fit & Not significant & $\mathrm{P}>0.05$ & $<0.08$ & & $>0.90$ & $>0.90$ \\
\hline
\end{tabular}

Table 6 Path analysis of six hypotheses

\begin{tabular}{|c|c|c|c|c|c|c|}
\hline Hypothesis & $\begin{array}{l}\text { Dependent } \\
\text { Variable }\end{array}$ & $\begin{array}{l}\text { Independent } \\
\text { Variable } \\
\end{array}$ & Estimate & S.E. & C.R. & $\mathrm{P}$ \\
\hline H1 accepted & Incentivization & BIM degree & $0.124 *$ & 0.045 & 2.730 & 0.006 \\
\hline H2 accepted & IPD acceptability & Incentivization & $4.284 * * *$ & 1.030 & 4.160 & $<0.001$ \\
\hline H3 accepted & Communication & BIM degree & $0.095 * *$ & 0.034 & 2.809 & 0.005 \\
\hline H4 accepted & IPD acceptability & Communication & $2.207 * *$ & 0.780 & 2.683 & 0.005 \\
\hline H5 accepted & Collaboration & BIM degree & $0.192 *$ & 0.072 & 2.677 & 0.007 \\
\hline H6 rejected & IPD acceptability & Collaboration & -1.867 & 1.283 & -1.455 & 0.146 \\
\hline
\end{tabular}

Note: $* * * \mathrm{p}<.001, * * \mathrm{p}<.005, * \mathrm{p}<.05$. 
731

732

733

734

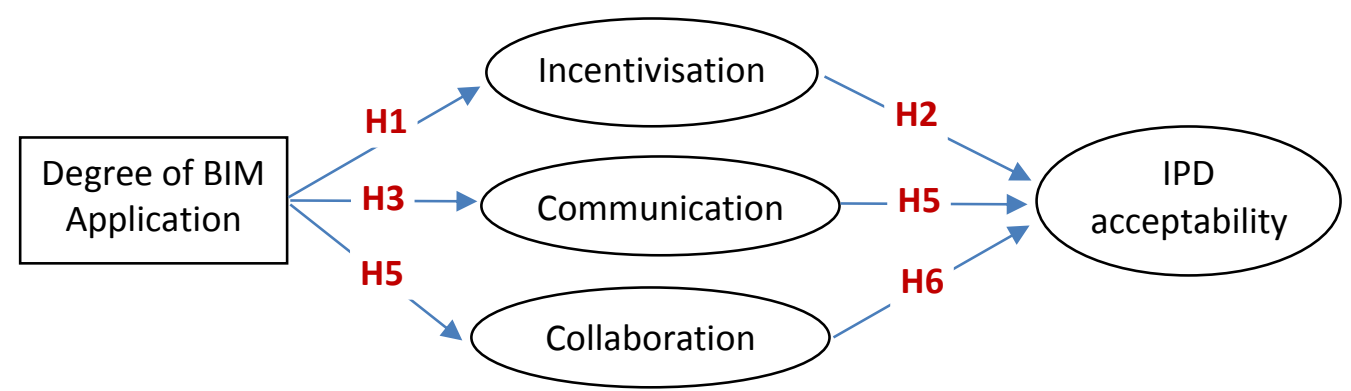

735

736

Figure 1. A Model of IPD Acceptability

737

738

739 


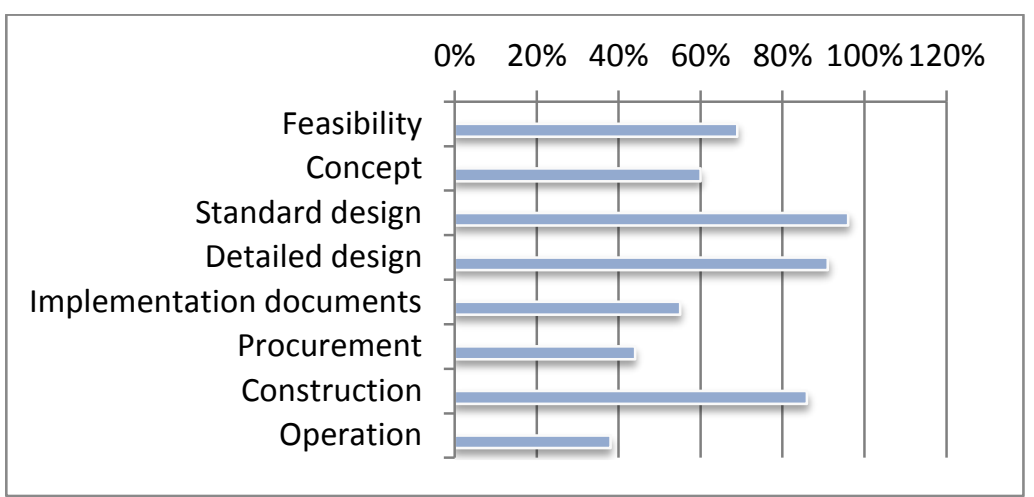

Figure 2. Project phases assisted by BIM

746

747

748

749

750

751

752

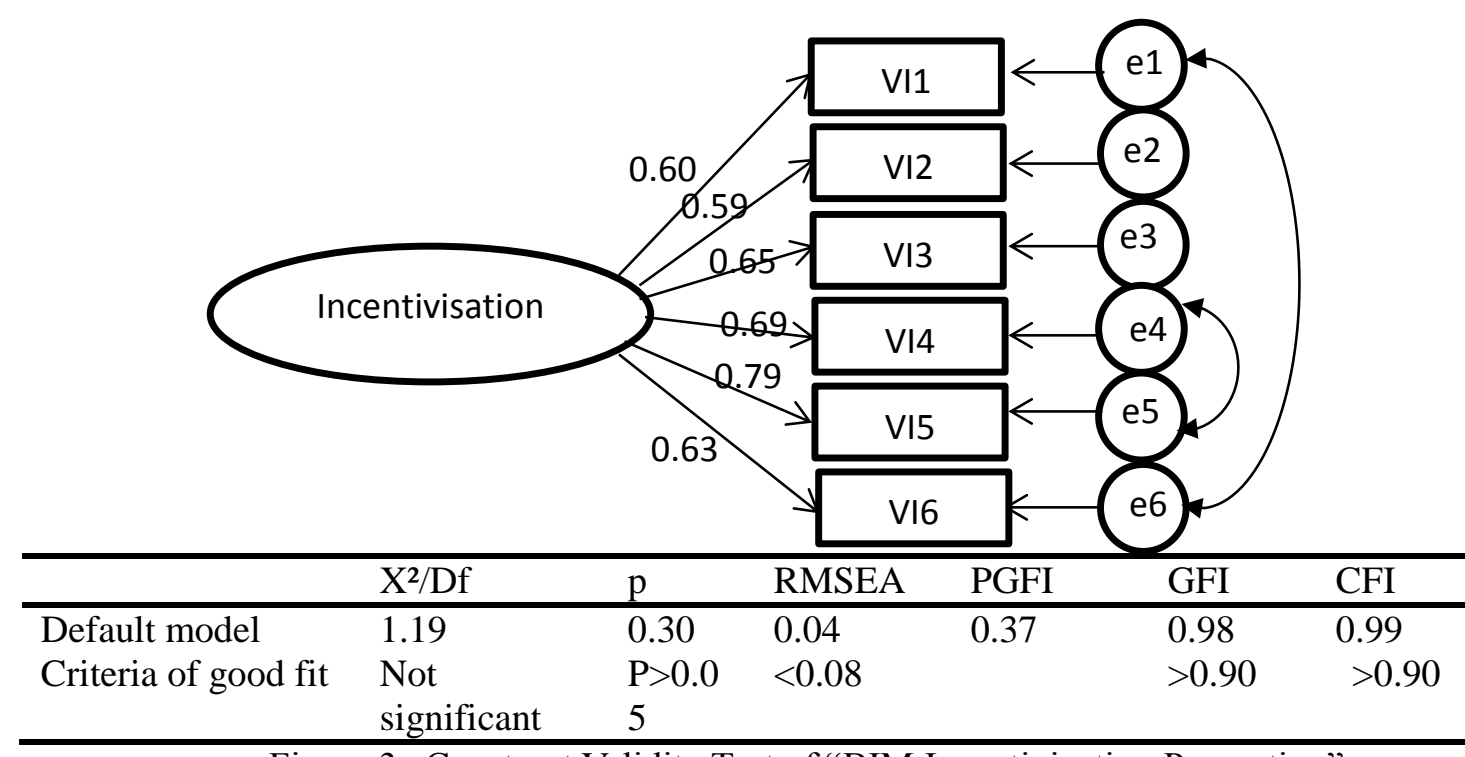

Figure 3a Construct Validity Test of "BIM Incentivization Perception"

753

754

755 
760

761

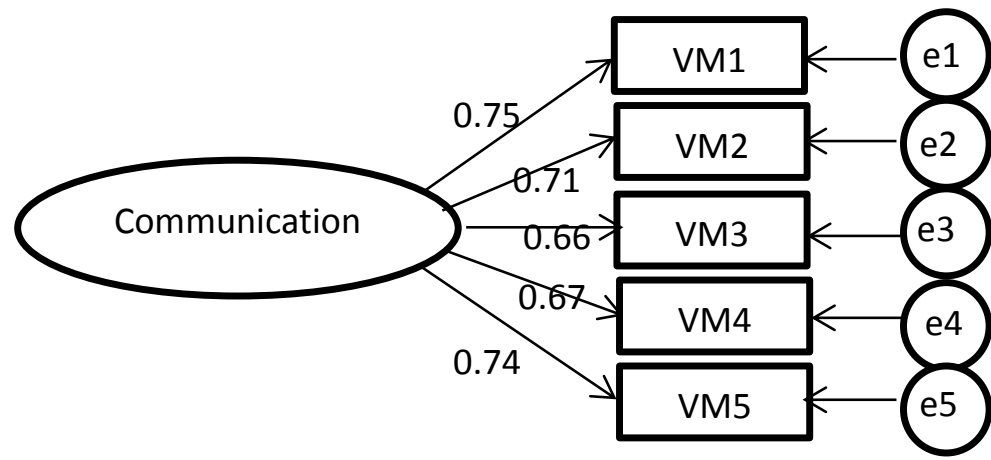

\begin{tabular}{llllllc}
\hline & $\mathrm{X}^{2} / \mathrm{Df}$ & $\mathrm{p}$ & $\mathrm{RMSEA}$ & $\mathrm{PGFI}$ & GFI & CFI \\
\hline Default model & 2.17 & 0.06 & 0.09 & 0.32 & 0.97 & 0.98 \\
Criteria of good & Not & $\mathrm{P}>0.05$ & $<0.08$ & $>0.5$ & $>0.90$ & $>0.90$ \\
& significant & & & & & \\
fit & & & & & & \\
\hline
\end{tabular}

762

763

Figure 3b Construct Validity of "Communication Quality"

764

765

766

767

768

769

770

771

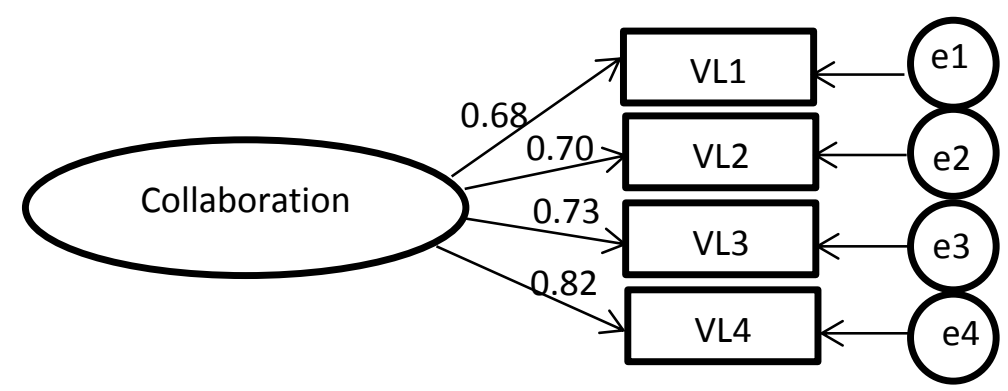

772

\begin{tabular}{lllllll}
\hline & $\mathrm{X}^{2} \mathrm{Df}$ & $\mathrm{P}$ & RMSEA & PGFI & GFI & CFI \\
\hline Default model & 1.00 & 0.37 & 0.01 & 0.20 & 0.99 & 1.00 \\
Criteria of good & Not & P $>0.05$ & $<0.08$ & $>0.5$ & $>0.90$ & \\
fit & significant & & & & $>0.90$ & \\
\hline
\end{tabular}

773

Figure 3c Construct Validity of "Collaboration"

775

776 


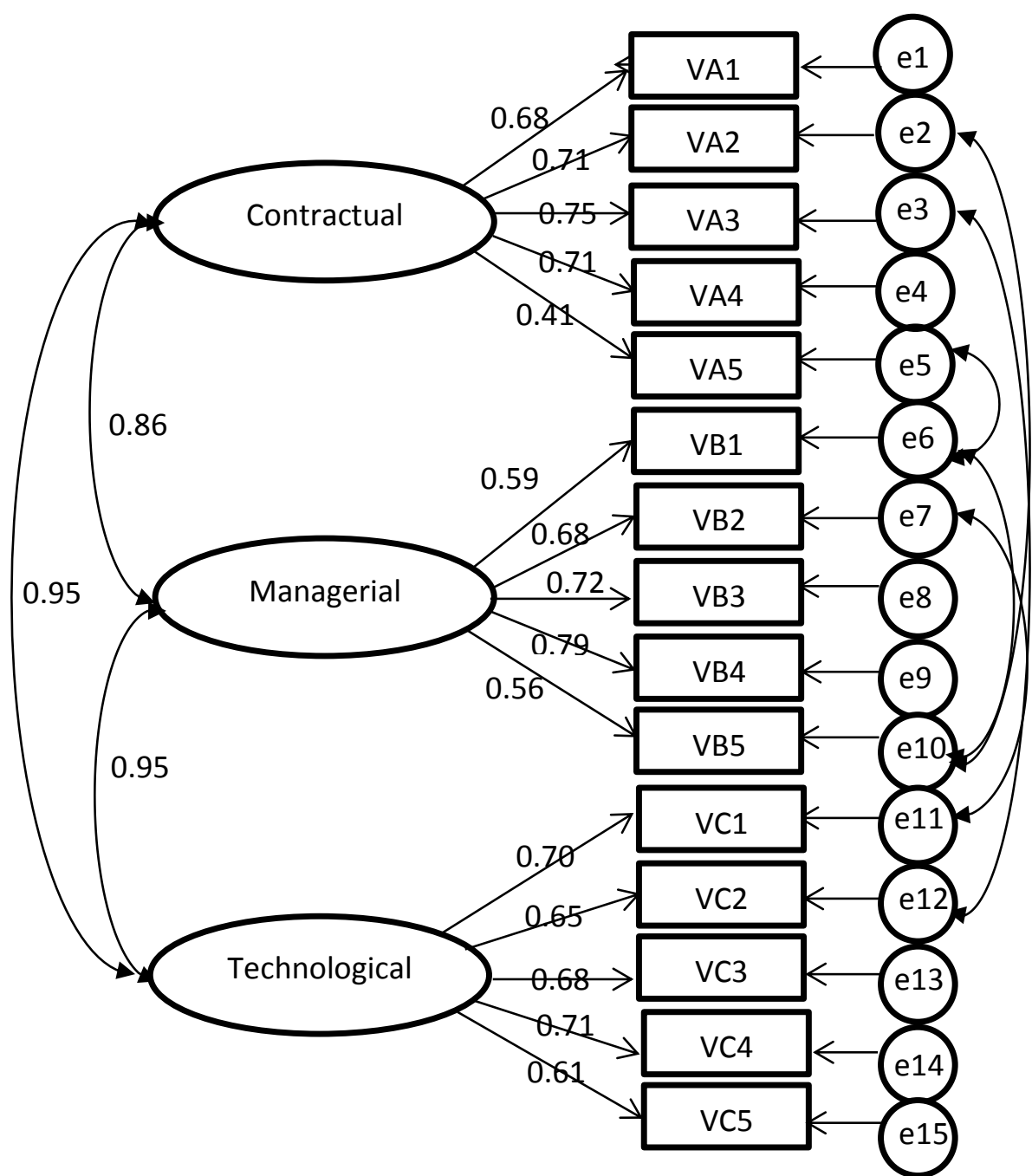

\begin{tabular}{lllllll}
\hline & $\mathrm{X}^{2} / \mathrm{Df}$ & $\mathrm{p}$ & RMSEA & PGFI & GFI & CFI \\
\hline Default model & 1.059 & 0.299 & 0.020 & 0.671 & 0.904 & 0.993 \\
Criteria of good fit & Not significant & $\mathrm{P}>0.05$ & $<0.08$ & $>0.5$ & $>0.90$ & \\
\hline
\end{tabular}


796

797

798

799

800

801

802

803

804

805

806

807

808

809

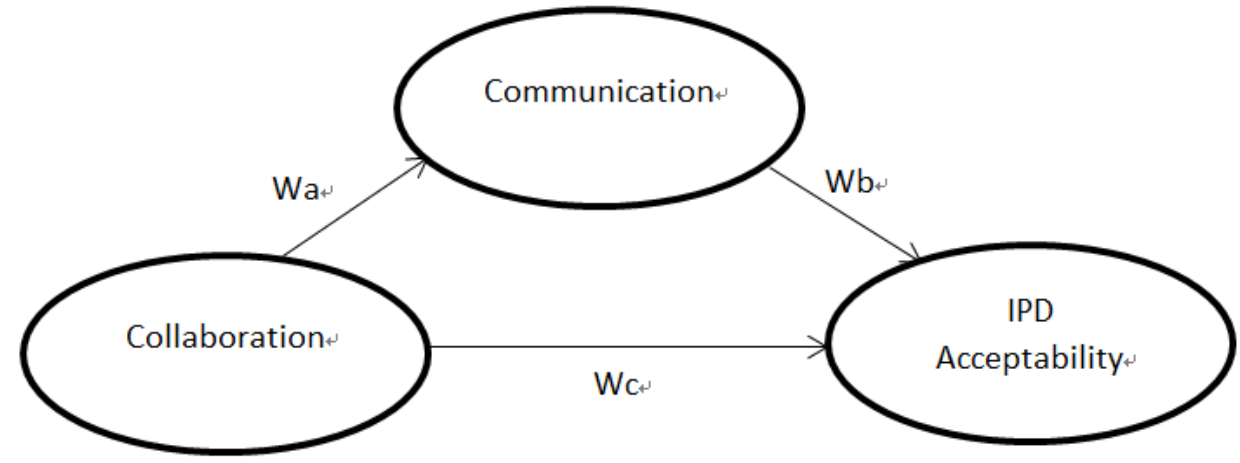

Figure 4 The mediation model of "Communication Quality"

\section{8}

9

.

1

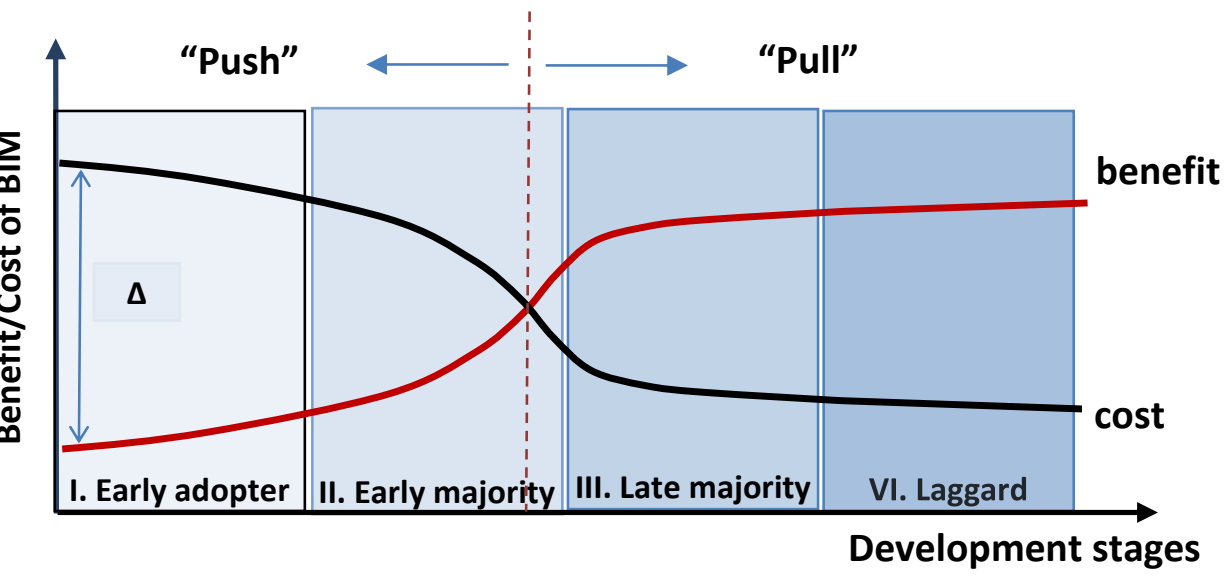

Figure 5 Trajectories of the cost and benefit of BIM deployment over different development stages 